This is an author produced version of a paper published in Annals of Applied Biology.

This paper has been peer-reviewed and is proof-corrected, but does not include the journal pagination.

Citation for the published paper:

A. Sigrun Dahlin, Atefeh Ramezanian, Colin D. Campbell, Stephen Hillier and Ingrid Öborn,. (2015) Waste recovered by-products can increase growth of grass-clover mixtures in low fertility soils and alter botanical and mineral nutrient composition. Annals of Applied Biology. Volume: 166, Number: 1, pp 105117.

http://dx.doi.org/10.1111/aab.12168.

Access to the published version may require journal subscription. Published with permission from: Wiley.

Standard set statement from the publisher:

This is the accepted version of the following article: A. Sigrun Dahlin, Atefeh Ramezanian, Colin D. Campbell, Stephen Hillier and Ingrid Öborn,. (2015) Waste recovered by-products can increase growth of grass-clover mixtures in low fertility soils and alter botanical and mineral nutrient composition. Annals of Applied Biology. Volume: 166, Number: 1, pp 105-117, which has been published in final form at http://dx.doi.org/10.1111/aab.12168. In addition, authors may also transmit, print and share copies with colleagues, provided that there is no systematic distribution of the submitted version, e.g. posting on a listserve, network or automated delivery.

Epsilon Open Archive http://epsilon.slu.se 
This is the peer reviewed version of the following article: Dahlin AS, Ramezanian A, Campbell CD, Hillier S, Öborn I. 2015. Waste recovered by-products can increase growth of grass-clover mixtures in low fertility soils and alter botanical and mineral nutrient composition. Annals of Applied Biology 166: 105-117, which has been published in final form at: http://onlinelibrary.wiley.com/doi/10.1111/aab.12168/abstract. This article may be used for non-commercial purposes in accordance With Wiley Terms and Conditions for self-archiving.

Title:

Waste recovered by-products can increase growth of grass-clover mixtures in low fertility soils and alter botanical and mineral nutrient composition.

Authors: A. Sigrun Dahlin ${ }^{a}$, Atefeh Ramezanian $^{b}$, Colin D. Campbell ${ }^{c, a}$, Stephen Hillier ${ }^{c, a}$ and Ingrid Öborn ${ }^{\text {b,d }}$

${ }^{\mathrm{a} D e p a r t m e n t}$ of Soil and Environment, Swedish University of Agricultural Sciences, P.O. Box 7014, SE-750 07

Uppsala, Sweden

${ }^{b}$ Department of Crop Production Ecology, Swedish University of Agricultural Sciences, P.O. Box 7043, SE-750 07

Uppsala, Sweden

'The James Hutton Institute, Craigiebuckler, Aberdeen, AB15 8QH, Scotland UK

${ }^{d}$ World Agroforestry Centre (ICRAF), UN Avenue, P.O. Box 30677-00100 Nairobi, Kenya

Corresponding author: Sigrun Dahlin

Phone: +46706712299

Fax: +4618673156

E-mail: Sigrun.Dahlin@slu.se

Short title: Recycling by-products to grass - clover mixtures 


\title{
Waste recovered by-products can increase growth of grass-clover mixtures in low fertility soils and alter botanical and mineral nutrient composition
}

\begin{abstract}
The effectiveness of four by-products (biogas digestate, pot ale, rockdust and wood ash) as fertilisers of a perennial ryegrass (Lolium perenne L.) - red clover (Trifolium pratense L.) mixture in terms of biomass production, botanical composition and macro- and micronutrient concentrations was tested in an outdoor pot trial. This was carried out over two growing seasons using two inherently low-fertility soils used for forage production. Macroand micronutrients ( $\mathrm{N}, \mathrm{P}, \mathrm{K}, \mathrm{Ca}, \mathrm{Mg}, \mathrm{Co}, \mathrm{Cu}, \mathrm{Mn}, \mathrm{Mo}$ and $\mathrm{Zn}$ ) relevant for crops and livestock were determined in soils and plants. All the by-products increased overall biomass production and affected nutrient concentrations of the individual plant species to varying degrees. In addition the competitive balance between grass and clover was altered leading to different botanical composition in the different treatments and consequently differences in the nutrient concentrations of the species mixture. Changes were due to the nutrients applied in the by-products per se and/or to changes in the soil chemistry caused by the by-products. The results suggest a potential to enhance agricultural productivity through improved production and quality of forage on less fertile land by matching of byproducts and soil properties.
\end{abstract}

Keywords: botanical composition, by-product recycling, crop growth, crop quality, macro- and micronutrient concentrations 


\section{Introduction}

The efficiency of using natural resources in crop production systems is an active area of research to meet needs both at farm level and for society in general. This includes the more efficient use of renewable plant nutrient resources found in recovered by-products as this has capacity to decrease Global Warming Potential and accumulated energy use in arable farming systems (Tuomisto et al., 2012). To be useful as fertilisers, these should provide suitable contents of plant-available macro- and micronutrients, and improve soil physical, chemical and biological conditions whilst minimizing transfers of deleterious elements or compounds to the soil. There is an increasing range of recovered by-products considered for use as soil amendments with widely varying composition especially in relation to micronutrients. However, the efficiency of these materials as fertilisers and possible sideeffects of their use at rates corresponding to crop needs and long-term nutrient balance in the receiving fields are often lacking. Instead, investigations have often focussed on the potential negative effects of by-product disposal at application rates higher than agronomic requirements (e.g. Bucknall et al., 1979; Etiegni et al., 1991; Krejsl and Scanlon, 1996), or on short-term effects such as shoot scorch after application in growing crops (Naylor and Shortreed, 1981).

Permanent and temporary grasslands, used as pastures or for ley production, are important land uses and cover large areas around the globe; e.g. in 2007 permanent grassland covered 33\% of the agricultural area in Europe (Eurostat, 2012). Grasslands can show high production capacity even on less fertile land and under low or moderate fertiliser nitrogen $(N)$ input, provided that they contain $\mathrm{N}_{2}$ fixing legumes. To realise this potential in full, macro- and micronutrient availability must be inherently sustainable or augmented on a regular basis. The less productive agricultural lands often used for forage production in Northern Europe tend to have low inherent nutrient supplying capacity through soil mineral weathering and thus require inputs of macro- as well as micronutrients to sustain their fertility (Edwards et al., 2012). Lower productivity coupled with increasing fertiliser costs significantly limits the economic margins from such land. Furthermore, most studies on fertilisation including amendments have been carried out on productive agricultural soils such that knowledge is lacking on their effectiveness on less-fertile soils.

On less fertile land legume-containing leys (temporary grasslands in crop rotations) play an important role providing high quality forage. Requirements regarding feed digestibility, crude protein concentration and energy value are strict in high-productivity animal production, and in particular for high-yielding dairy cows. Furthermore, in addition to macronutrients, micronutrients such as essential cobalt (Co), copper (Cu), iodine (I), iron (Fe), manganese $(\mathrm{Mn})$, selenium (Se) and zinc $(\mathrm{Zn})$ as well as beneficial molybdenum (Mo) and nickel (Ni) are important components of good ruminant nutrition (Suttle, 2010); and concentrations of these nutrients are often higher in clover than in grasses (e.g. Pirhofer-Walzl et al., 2011; Lindström et al., 2013). 
Mixtures of grasses and legumes often produce forage of higher digestibility and protein content compared to grass-only (Sleugh et al., 2000; Bertilsson and Murphy, 2003), lead to higher feed intake (Bertilsson and Murphy, 2003) and - unless the leys are heavily $\mathrm{N}$ fertilised - give more even biomass production across the growing season compared with pure grass leys (Sleugh et al., 2000). Hence the balance between grasses and legumes such as clover is an extremely important objective in managing pastures. Species mixtures result invariably in more complex crop responses to fertilisation or soil amendments because the individual species may react quite differently due to their differing nutritional requirements and tissue concentrations (Cope and Rouse, 1977; Lindström et al., 2013). It is a significant challenge therefore to increase production levels of mixed stands while maintaining the desired botanical composition of the ley and also to evaluate experimental results from them. However, as these forage species are frequently intercropped it is essential to carry out an evaluation of fertiliser effects in mixed stands.

The objective of the present study was to evaluate the fertiliser value of selected organic and inorganic byproducts in terms of their ability to increase biomass production and affect the mineral composition of forage crops (mixtures of red clover and perennial ryegrass) on low-fertility soils. The following specific hypotheses were tested: 1) the by-products can all be used to improve the bioavailability of both macro- and micronutrients to plants by adding additional nutrients and altering soil properties; 2 ) as a consequence, overall crop growth will increase with addition of amendment, but the differing nutrient and pH preferences of the individual species will lead to different botanical compositions; 3) wood ash and rockdust add plant-available nutrients (except N) and increase soil pH; 4) pot ale liquor specifically increases $\mathrm{Cu}$ availability, uptake and plant concentration; 5) biogas digestate adds a balanced mix of plant-available nutrients reflecting the composition of the biogas feedstock. To test these hypotheses one soil was selected from each of two agricultural areas with coarse textured soils derived from nutrient-poor parent material. In order to avoid effects of differing weather and drainage conditions on the nutrient uptake and composition of the plants (Roche et al., 2009), these soils were used in an outdoor pot experiment where these conditions could be kept equal. In order to understand the plant-soil-amendment interactions, we grew a model grass/clover mixture but have assessed growth and nutrient uptake separately for each species.

\section{Materials and methods}

A pot experiment with a completely randomised design with 4 replications was established in summer 2009 and treatment effects determined the following year. To ensure relevance to farmers' practice, application rates conformed to national regulations and guidance (Swedish Environmental Protection Agency, 1994 and Swedish Board of Agriculture, 2004). A mixture of red clover (Trifolium pratense L., cv. Nancy) and perennial ryegrass (Lolium perenne L., cv. Helmer) was used as a simplified model of the mixed ley stands in common use. Top soils with low nutrient status were used (Table 1) as representatives of soils derived from highly siliceous parent material that is common for Northern European grassland soils. Hollsby $\left(59^{\circ} 48^{\prime} \mathrm{N}, 13^{\circ} 31^{\prime} \mathrm{E}\right)$ is a postglacial silt loam 
originating from mainly granitic and sandstone bedrock and used for grazing on semi-natural grassland (Table 2). Rådde $\left(57^{\circ} 36^{\prime} \mathrm{N}, 13^{\circ} 15^{\prime} \mathrm{E}\right)$ is a till with sandy loam texture developed from gneissic and granitic parent material and used for ley production.

Treatments

The by-products were selected based on their relative concentrations of macro- and micronutrients and nonnutrient elements and an assessment of potential volumes available to the agricultural sector. They included a volcanic (pyroxene-andesite) rockdust (Cameron et al., 2010; Ramezanian et al., 2013) as sole amendment or in combination with $\mathrm{N}$, bottom ash from mixed deciduous wood as sole amendment or in combination with $\mathrm{N}, \mathrm{a}$ whiskey distillery by-product (pot ale) and biogas digestate from a biogas plant fed with source separated household waste and grass silage (Table 3). A fully fertilised treatment in split applications (in spring and after harvest 1 and 2; Table 3) and an unamended control were included for comparison. As a general rule the byproducts were applied at the maximum allowable 7-year application rates of nutrient and non-nutrient elements as stated by the Swedish Environmental Protection Agency (1994) for trace elements (cadmium (Cd), chromium $(\mathrm{Cr}), \mathrm{Cu}$, mercury ( $\mathrm{Hg}), \mathrm{Ni}$, lead (Pb), and $\mathrm{Zn}$ ), and the Swedish Board of Agriculture (2004) for P. However, to maintain a desirable proportion of clover the $\mathrm{N}$ application rate via biogas digestate and pot ale was set at $150 \mathrm{~kg}$ total $\mathrm{N}^{-1} \mathrm{a}^{-1}$ equivalent. On the other hand, low plant availability of elements was anticipated for the rockdust applications; hence the trace element limitation prescribed by Swedish Environmental Protection Agency was exceeded (for $\mathrm{Ni}, \mathrm{Cr}$ ) and a higher application rate as recommended by the rockdust supplier was used. The mineral $\mathrm{N}$ application rate in the fully fertilised treatment and rockdust $+\mathrm{N}$ and wood ash $+\mathrm{N}$ treatments was similarly set to achieve a balanced mix of grass-clover in the pots. All by-products (and the full fertilisation) were applied before establishment of the experimental crop in the summer 2009. In spring 2010 and after the first harvest, macronutrients were again added to the fully fertilised treatment and $\mathrm{N}$ was added in the rockdust $+\mathrm{N}$ and wood ash $+\mathrm{N}$ treatments. The first and second harvest results suggested NPK were still the major limiting factors to the evaluation of the by-products. Hence, after the second harvest we augmented with NPK to evaluate separately the effects from other component nutrients; however, rockdust- $\mathrm{N}$ and wood ash- $\mathrm{N}$ treatments did not receive any additional $\mathrm{N}$.

Establishment, growth conditions and samplings

Both soils were sieved through an $8 \times 18 \mathrm{~mm}$ aluminium mesh and thoroughly homogenised before use in the pot experiment. At establishment, fresh soil (corresponding to 6 kg dry weight (DW)) was mixed with the respective amendments, transferred to each pot (220 mm inner $\varnothing, 250 \mathrm{~mm}$ depth) and on 27 July 2009 sown with a mixture of red clover and perennial ryegrass which were thinned to 10 plants of each species per pot approximately two weeks after emergence. The pots were subsequently kept outdoors under semi-natural conditions in a netted, unroofed area and irrigated with deionized water as needed to complement precipitation. During the 
establishment year, plants were left intact for the entire growth period, and then overwintered in a climate chamber at $-1^{\circ} \mathrm{C}$ to $+1^{\circ} \mathrm{C}$.

The plants were harvested 15 June, 20 July, and 20 August 2010 and at all three harvests the clover was between stem elongation and early flowering stage and the grass was at earing stage. Before harvest the plants were showered with deionized water to minimize plant contamination by dust. Plants were subsequently cut at $5 \mathrm{~cm}$ above soil level with stainless steel scissors, sorted into clover and grass and dried in perforated plastic bags at $50^{\circ} \mathrm{C}$ in a forced-ventilation dryer for at least $48 \mathrm{~h}$. The plant samples were weighed and milled to a particle size below $1 \mathrm{~mm}$ using a cutting mill with a titanium knife (Grindomix GM 200, Retsch GmbH). Precautions to counteract trace element contamination (Dahlin et al., 2012) were taken at all handling steps.

Soil sampling was carried out on 22-29 September 2010, all pots of one replicate per day. Ten cores were taken from each pot using a corer ( $9 \mathrm{~mm}$ inner $\varnothing$ ) to the pot's full depth, and the samples air dried.

Chemical analyses

Soil samples, wood ash and rockdust, were a) digested in concentrated $\mathrm{HNO}_{3}, \mathrm{HCl}$ and $\mathrm{HF}$ in closed Teflon containers in a microwave digestion system and $\mathrm{Cd}, \mathrm{Co}, \mathrm{Cr}, \mathrm{Cu}, \mathrm{Hg}, \mathrm{Mo}, \mathrm{Ni}, \mathrm{Pb}$, sulphur (S) and $\mathrm{Zn}$ measured on ICPSFMS (sector technique), and b) fused with lithium metaborate, then dissolved in $\mathrm{HNO}_{3}$ and aluminium (Al), $\mathrm{Ca}, \mathrm{K}$, magnesium (Mg), Mn and P measured by ICP-AES. Biogas digestate, pot ale and the plant material were digested in concentrated ultrapure $\mathrm{HNO}_{3}$ and $\mathrm{HF}$ in open vessels in a microwave oven, followed by filtering, and measurement of all elements on ICP-SFMS.

Total $\mathrm{N}$ and $\mathrm{C}$ concentrations in plant and soil samples were analysed by high temperature induction furnace combustion using LECO CN2000 (LECO Corporation, St Joseph, MI, USA). Soil electrical conductivity (EC) was measured in a solution of deionized water and thereafter $\mathrm{CaCl}_{2}$ was added $(0.01 \mathrm{M}$ ) and $\mathrm{pH}$ determined (Sumner, 1994). EDTA extractable P, K, Ca, Mg, S, Co, Cu, Mn, Mo and Zn were analysed after extraction according to Streck and Richter (1997) although Na-EDTA was used and the extracts were analysed by ICP-MS ELAN 6100 DRC (Perkin Elmer SCIEX, Waltham, MA, USA). EDTA extractable concentrations are reported as $\mathrm{Ca}_{\text {EDTA }}, \mathrm{CO}_{\text {EDTA }}$, etc.

Certified reference material (NIST Wheat Flour, National Institute of Standards and Technology, Gaitersburg, MD, USA) was included in all batches for plant material analysis. For soil analyses an in-house standard was included in each batch.

Soil particle size distribution was determined according to ISO 11277:1998 (ISO, 1998), and cation exchange capacity (CEC) and base saturation (BS) calculated from Parker (1929) and Thomas (1982). Phosphorus, K, Ca, and Mg were extracted with ammonium lactate/acetic acid (AL) solution (Swedish Standards Institute, 1993) for comparison with Swedish soil maps. The mineralogical composition of $<2 \mathrm{~mm}$ soil was determined by XRD on spray 
dried random powder samples (Hillier, 1999) and quantitative analyses done using a full pattern fitting method (Omotoso et al., 2006).

All-season average concentrations of the nutrients taken up by the plants were calculated by weighting of biomass DW at each harvest, and overall nutrient concentrations of the species mixtures calculated by taking into account the botanical proportion of each species in each mixture. The nutrient off-take was also calculated, here defined as the total amount of macro- and micronutrients removed with the total (i.e. summed grass and clover) biomass harvested per unit area.

Statistical analysis

Statistical analysis was done using the JMP 10.0.0 (SAS Institute Inc., Cary, NC, USA) two-factorial variance analysis including by-product/fertiliser treatment and soil type in the data. When needed, data were transformed to the natural logarithm or square root to achieve normal distribution of residuals. Multiple linear regressions followed by pairwise correlations were performed using the Holm (1979) method to control the family-wise error of the multiple regressions; plant biomass accumulation was tested vs plant concentrations of all measured nutrients, and vs soil $\mathrm{pH}$; plant concentrations of all nutrients were tested vs soil pH; and plant concentrations were tested vs the respective EDTA extractable soil concentrations. All differences described in the text are significant at $p<0.05$.

\section{Results}

Soil response to amendment

The pH range across all treatments was 4.6-5.4 (Hollsby) and 4.4-5.4 (Rådde) (Table 4). Across soils, pH was significantly higher after wood ash application (average $\mathrm{pH}$ 5.2) than in the unamended control and most other byproduct amended soils (average pH 4.9). The EC was similar in all by-product amended and non-amended soils but higher in the fully fertilised treatment (Table 4).

The wood ash amended soils had higher EDTA extractable concentrations of $\mathrm{Ca}, \mathrm{K}$ and $\mathrm{Mg}$ compared with other treatments but low-to-average concentrations of other nutrients (Table 4). The pot ale treatment had the highest $\mathrm{Cu}_{\text {EDTA }}$. The fully fertilised treatment frequently had higher than average EDTA extractable concentrations, but had the lowest average $\mathrm{Cu}_{\mathrm{EDTA}}$ on the Hollsby soil.

Plant biomass harvested

Grass growth was strong during spring but subsequently declined, whereas the opposite was true for the clover (data not shown). The additional fertilisation with $\mathrm{N}, \mathrm{P}$ and $\mathrm{K}$ after the second harvest did not significantly increase growth of either clover or grass, except that of clover on the rockdust amended Rådde soil. However, on average this fertilisation more than doubled the plant $\mathrm{K}$ concentration and to a smaller degree increased the $\mathrm{P}$ 
concentration in most of the treatments while it decreased the plant Mg concentration compared to the second harvest. Nevertheless, as the overall treatment effects were similar at each harvest, data are presented averaged across the growing season.

The harvested plant biomass was strongly affected by the amendments (Fig. 1A and B), with higher grass biomass on soils amended with by-products containing plant available $\mathrm{N}$ or receiving mineral $\mathrm{N}$ (fully fertilised, pot ale, and wood ash and rockdust in combination with $\mathrm{N}$ ). However, treatments with high grass biomass generally had a relatively small clover biomass (except for the fully fertilised treatment.) This was most clearly seen where mineral $\mathrm{N}$ was applied along with wood ash and rockdust as compared to when wood ash and rockdust were added alone. The total biomass production subsequently varied less, but was significantly higher on all amended soils compared with the unamended control and particularly high on the fully fertilised soil. As a result of the different response of clover and grass to the by-products and the mineral fertilisation, the botanical composition of the species mixture differed widely from $20-50 \%$ clover in the wood ash $+\mathrm{N}$, rockdust $+\mathrm{N}$ and fully fertilised treatments to around $75 \%$ clover in the wood ash and rockdust amended treatments (Fig. 1A and B).

Clover and grass nutrient concentrations

Plant nutrient concentrations in the unamended control was frequently low indicating that more than one nutrient may have restricted growth. Clover concentrations were at or below reported critical concentrations of $\mathrm{K}$ (both soils), Mg (Rådde) and P (Rådde), and close to reported critical concentrations for N (both soils) and P (Hollsby) (Supp. 1A and B). Grass concentrations of $\mathrm{K}$ (both soils), N (both soils) and P (Rådde) were below critical concentrations, and close to critical concentrations for Cu (Hollsby), Mg (both soils) and P (Hollsby) (Supp. 2A and B). From a fodder perspective, the species mixtures were below recommended concentrations for Co (Rådde), Cu (Rådde), N (both soils) and Zn (Hollsby), and close to the lowest recommended concentrations for $\mathrm{K}$ (both) and Mg (Rådde) (Supp. 3A and B).

Amendment and fertiliser applications lead to lower clover concentrations of $\mathrm{Cu}$ and $\mathrm{N}$ on both soils and $\mathrm{P}$ on Hollsby soil. Clover from the wood ash treatment generally had among the lowest concentrations of $\mathrm{Ca}$, Co, $\mathrm{Cu}$ and $\mathrm{N}$, for both soils (Fig. 2A and B). The fully fertilised treatment generally showed low clover concentrations of $\mathrm{Cu}$ and Mo, but high $\mathrm{K}, \mathrm{Mg}, \mathrm{Mn}$ and $\mathrm{N}$. The biogas digestate, pot ale, and rockdust (with or without N) generally showed intermediate nutrient concentrations. When wood ash or rockdust application was combined with $\mathrm{N}$, clover concentrations of $\mathrm{Ca}, \mathrm{Mg}$ and Mo were significantly higher than when grown without $\mathrm{N}$, and for rockdust also $\mathrm{Co}$ and $\mathrm{Mn}$ were higher. There was also a tendency for lower K concentrations in both wood ash and rockdust amended soils when $\mathrm{N}$ was added. 
After by-product amendment or fertilisation, grass $\mathrm{Cu}$ and $\mathrm{Ca}$ concentrations were lower on both soils and $\mathrm{Mg}$, Mo and $\mathrm{P}$ concentrations on the Hollsby soil (Fig. 3A and B). In the wood ash and rockdust treatments, Ca, Co and N were higher and $\mathrm{K}$ lower when $\mathrm{N}$ was applied, which differed from the effects on the clover.

Analysed across all treatments and both soils, clover had significantly higher concentrations of Ca (240\%), Co (30\%), Cu (140\%), Mg (70\%), Mo (5\%), N (80\%) and Zn (80\%) than the grass, whereas concentrations were lower for $\mathrm{K}(30 \%)$ and $\mathrm{Mn}(50 \%)$ (Supps. $1 \mathrm{~A}$ and $\mathrm{B}$, and $2 \mathrm{~A}$ and $\mathrm{B})$. Phosphorus concentrations were similar and not significantly different between species. On both soils, $\mathrm{K}$ in clover and grass was low in relation to reported plant needs, and $\mathrm{P}$ and $\mathrm{Cu}$ concentrations were also similarly low in relation to plant needs in some treatments (Supps. $1 \mathrm{~A}$ and $\mathrm{B}$, and $2 \mathrm{~A}$ and $\mathrm{B}$ ). Magnesium concentrations apparently did not meet the plant demand in some treatments on the Rådde soil.

Overall nutrient concentrations and off-takes of the species mixture

Overall nutrient concentrations of the mixtures were strongly affected by the treatments, with a median ratio of 1.9 between the highest and lowest concentrations within each soil (Fig. 4a and b, Suppl. 3a and b). For example, Mg concentrations were higher on the rockdust and wood ash amended soils than on the ones amended by pot ale and digestate, $\mathrm{Cu}$ and $\mathrm{Zn}$ were generally high after digestate application, but Cu low after pot ale amendment, and $\mathrm{Co}, \mathrm{Mn}$ and $\mathrm{Zn}$ low on the rockdust and wood ash amended soils. Application of $\mathrm{N}$ with the rockdust or wood ash generally decreased the overall concentrations of $\mathrm{Ca}, \mathrm{Cu}, \mathrm{K}$ and $\mathrm{N}$ on both soils and $\mathrm{Mg}$ on Hollsby soil.

The nutrient off-take with harvested biomass reflected nutrient concentrations as well as the biomass production of the clover and grass, respectively (Supp. $4 a$ and b). The fully fertilised treatment thus generally showed the highest off-takes. The unamended control showed low off-takes for all nutrients, but Mn off-take was lowest from the wood ash and wood ash $+\mathrm{N}$ fertilised soils, and off-take of $\mathrm{Cu}$ was lowest from the pot ale and wood ash $+\mathrm{N}$ fertilised soils. Simultaneous application of $\mathrm{N}$ with the wood ash or rockdust produced significantly lower off-takes of $\mathrm{Ca}, \mathrm{Cu}, \mathrm{Mg}, \mathrm{K}$, and $\mathrm{N}$ compared to wood ash or rockdust only, but higher $\mathrm{Mn}$ off-takes for the rockdust fertilised soils.

Relations between soil characteristics, plant composition and growth

Amendment affected plant growth and nutrient concentrations depending on by-product composition and soil availability of the respective nutrients. Increasing soil pH generally was correlated with decreasing plant concentrations of $\mathrm{Cu}, \mathrm{Mn}$ and $\mathrm{Zn}$ but with increasing plant Mo (both soils) and P (Hollsby) concentrations (Supp. 5). Biomass accumulation was, however, not significantly correlated with $\mathrm{pH}$ on either of the soils. 
Correlations between plant nutrient concentrations and EDTA extractable soil concentrations were mainly with $\mathrm{K}$, Mg and Zn (Supp. 5). Direct correlations between nutrient application rates and increased plant concentrations of the same nutrient were seen only for $\mathrm{K}$ (Hollsby clover $p=0.0023$; Rådde grass $p=0.0003$ ).

Clover biomass accumulation was inversely correlated with its $\mathrm{Mg}$ and Mo concentrations on the Hollsby soil (Supp. 5). Grass biomass was directly correlated with plant Mn and Zn concentrations but inversely correlated with plant Mo concentration. On the Rådde soil, grass biomass was directly correlated with plant Co, K, Mg and P concentrations.

\section{Discussion}

Testing the by-products in a pot experiment serves as a first step and needs to be followed by testing in the field. However, it gave the opportunity to test their effects on different soils under semi-controlled and equivalent conditions. The soils selected had low concentrations of $\mathrm{K}, \mathrm{Mg}$ and several micronutrients compared with arable soils in Northern Europe (Reimann et al., 2000; Eriksson et al., 2010; Paterson, 2011; Swedish Monitoring Program, 2013). They thus served as representatives of soils commonly used for grazing and forage production and the potential for detecting any fertiliser effects of $\mathrm{K}, \mathrm{Mg}$ and several micronutrients of the by-products was deemed to be good. Both soils had low $\mathrm{pH}$, although not extreme for this type of land use. Nevertheless the low $\mathrm{pH}$ will have improved the availability of a majority of the micronutrients (Alloway, 2013), possibly contributing to sufficient plant uptake in spite of the low total soil concentrations of some of these nutrients.

Effects of by-product application on biomass production

Total biomass harvested was low on the unamended soils, much higher in the fully fertilised treatment, with the by-product amended treatments falling between these two extremes. This indicates that biomass production on the unamended soils was impeded primarily by nutrient supply. It was further evident that total biomass production was increased by all the by-products applied to these soils. Such increases have been reported for digestate-amended soils (Gunnarsson et al., 2010; Grigatti et al., 2011) and pot ale-amended soils (Douglas et al., 2003). This has also been reported for wood ash-amended soils (as reviewed by Demeyer et al., 2001), although application rates have often been considerably higher than agronomic requirements. Yield increases have also been reported after amendment with mafic rockdust (e.g. Kahnt et al., 1986; Bakken et al., 2000) although no yield effect was found by Campbell (2009) and Ramezanian et al. (2013) of the same type of andesitic rockdust as that used in the current experiment. The contrasting results highlight the importance of the original nutrient status of the soils for the scope of detecting nutrient supply from by-products, and also determine whether these products may potentially be useful as amendments to the respective soils. Rockdust may be most suitable therefore for soils with low capacity to supply plant nutrients, especially for $\mathrm{K}, \mathrm{Ca}$ and $\mathrm{Mg}$.

Clover and grass respond differently to treatments 
The increased grass and decreased clover biomass production upon $\mathrm{N}$ fertilisation confirmed the increased competitiveness of perennial ryegrass vs. clover under high $\mathrm{N}$ availability and a shift in botanical composition frequently seen in swards under increased $\mathrm{N}$ fertilisation (Harris et al., 1996; Elgersma et al., 2000). However, byproducts containing little or no $\mathrm{N}$ in this experiment (i.e. the wood ash and rockdust) also led to a shift in botanical composition compared to the unamended control, albeit with an increase in the proportion of the clover. Data from Ferreiro et al. (2011) also suggest that the white clover proportion in ash-amended leys increased relative to the unamended control in a similar manner, although this was not specifically tested in that study. The two organic by-products gave intermediate but distinctly different botanical composition. Consequently the agronomic management of clover in such low fertility soils needs to consider carefully the effect of amendments on the sward composition.

Both inherent soil properties and by-products affect grass and clover nutrient concentrations

The macro- and micronutrient concentrations of the grass and clover grown on the two soils was apparently affected by the inherent nutrient-supplying capacity of the soil, by the application of nutrients per se and indirectly through effects the amendments had on $\mathrm{pH}$ or the ionic composition of the soil solution. For example, the direct correlation between grass $\mathrm{K}$ concentration and harvested biomass on Rådde soil and a tendency towards a correlation on Hollsby soil, combined with the low plant concentrations suggests that K deficiency was limiting growth in some treatments on both soils. Potassium and $\mathrm{Mg}$ supply from the by-products was clearly indicated as both plant nutrient concentrations and off-takes increased, although to a differing extent; e.g. on average across the soils wood ash increased clover $\mathrm{K}$ and $\mathrm{Mg}$ concentrations by 55 and 35\%, respectively, and total plant off-takes by $115 \%$ and $140 \%$, respectively, compared with the unamended control. However, the results suggest $\mathrm{K}$ supply was still limited. Although Öborn et al. (2010) found a clear growth limitation only at a ryegrass K concentration of $1 \%$, critical or sufficiency concentrations reported by Whitehead (2000) and Mengel (2007) suggest that grass as well as clover $\mathrm{K}$ concentrations were in the suboptimal range. The decreased $\mathrm{K}$ concentrations in the $\mathrm{N}$-fertilised grass thus indicate a dilution effect (Jarrell and Beverly, 1981) through enhanced biomass accumulation which could not be matched by a corresponding increase in $\mathrm{K}$ uptake in spite of the $\mathrm{K}$ application via the wood ash or rockdust.

The correlation of plant nutrient concentrations or off-takes vs. EDTA-extractable soil concentrations was strong for $\mathrm{Zn}$ on both soils, for $\mathrm{Mn}$ on the Hollsby soil and $\mathrm{K}$ and $\mathrm{Mg}$ on the Rådde soil, but otherwise often weak, which illustrates that EDTA extraction is often only a crude estimate of plant available fractions of nutrients (e.g. SorianoDisla et al., 2010). A particularly striking example of this was the EDTA extractable Cu concentration in the soils treated with pot ale which was highest of all treatments for both soils, but where the clover concentration and the total off-take were among the lowest. This indicates that $\mathrm{Cu}$ in the plant biomass not only was diluted due to increased growth (e.g. Reith et al., 1984; Kopsell and Kopsell, 2007), but also that the pot ale Cu was poorly available to the plants or other factors were reducing its uptake. 
The availability of a number of micronutrients is known to be strongly affected by $\mathrm{pH}$ (Alloway, 2013). The $\mathrm{pH}$ increase from 5.0 to 5.4 in Hollsby and from 4.6 to 5.2 in Rådde could be expected to affect plant availability of nutrients in the wood ash and wood ash $+\mathrm{N}$ treatments. Clover and grass concentrations of $\mathrm{Co}, \mathrm{Cu}, \mathrm{Mn}$ and $\mathrm{Zn}$ were indeed low in these treatments whereas Mo concentrations were high. Other studies have also revealed decreased plant concentrations of micronutrients such as $\mathrm{Cu}$ and Mn (Krejsl and Scanlon, 1996) but increased plant Mo concentrations (Park et al., 2012) after wood ash application and these effects were attributed to an increased $\mathrm{pH}$. However, in our experiment only off-takes of Mn were decreased compared with the control, suggesting that dilution due to increased biomass accumulation (Jarrell and Beverly, 1981) may have been a contributing factor for the decreasing plant concentrations at least for the remaining nutrients (Co, $\mathrm{Cu}$ and $\mathrm{Zn}$ ).

Effects of botanical composition on plant mixture mineral concentrations

Enhanced $\mathrm{N}$ nutrition affected the species mixtures' overall nutrient concentrations and off-take via effects on the botanical composition and nutrient concentrations of the individual species. Application of $\mathrm{N}$ with wood ash and rockdust increased plant concentrations of a majority of the macro- and micronutrients in the clover and/or the grass. Increased plant concentrations in response to $\mathrm{N}$ fertilisation were also reported by Fangmeier et al. (1997) for $\mathrm{Ca}, \mathrm{Mg}, \mathrm{N}$, and $\mathrm{Zn}$ in wheat at the beginning of shoot elongation although the relation was inversed at later phenological stages. The increased nutrient concentrations of the plant mixture, however, cannot with certainty be interpreted in terms of enhanced nutrient availability in the soil as nutrient off-takes in our experiment often did not show the same trend. For example, Ca (in both plant species) and N (in grass) concentrations increased upon $\mathrm{N}$ fertilisation but overall concentrations and total off-takes generally decreased. These disparate results were due to a shift in botanical composition of the species mixtures to one dominated by the grass which had lower Ca and $\mathrm{N}$ concentrations than the clover, and confirms the decreased $\mathrm{N}$ off-take previously found in mixed white cloverperennial ryegrass leys upon $\mathrm{N}$ fertilisation (Elgersma et al., 2000). The impact of $\mathrm{N}$ fertilisation on the botanical composition obviously had a strong impact on the overall nutrient concentrations and total off-takes of the species mixture.

Implications for the feeding value of the species mixture

The tested by-products all affected the botanical composition. Such changes have implications for the feeding value of a species mixture. A balanced diet is of utmost importance for animal productivity and health, and especially so in dairy production. Legumes may increase the concentrations of most macro- and micronutrients in the forage crop as shown here, and by Lindström (2013), Pirhofer-Walzl et al. (2011) and Govasmark et al. (2005). In addition, legumes have the potential to increase forage digestibility, energy value and the cows' feed intake, all needed for high milk production (Bertilsson and Murphy, 2003). Where clover-grass leys contribute a large proportion of the diet, ley fertilisation should thus be adjusted so that the desired botanical composition is 
achieved. The change in overall macro- and micronutrient composition of the mixtures also has implications for the need for mineral nutrient supplementation. In this experiment, biogas digestate and rockdust amendment increased crop mixture concentrations of $\mathrm{Cu}$ and $\mathrm{Zn}$ to close to or over the minimum concentrations recommended by the US National Research Council (NRC) (2001; Supp. 3a and b). The rockdust and wood ash increased crop Mg concentrations which can be of importance where grass tetany (hypomagnesaemia) occurs.

The data indicate that the by-products can improve both forage quantity and quality on nutrient-poor soils in the absence of fertilisers or as a complement to macronutrient fertilisation. However, the results from pot experiments should always be evaluated cautiously and evaluation via field experiments should be the next essential step. Studies on other aspects of by-product recycling are also likely to be needed to secure safe and long-term sustainable use of by-products as fertilisers. These include more in-depth characterisation of the byproducts and a process based understanding of the factors that lead to the observed behaviours. Monitoring of soil quality (e.g. by using soil health indicators and element input-output mass balances of nutrients and nonnutrients) and consideration of long term ecological effects are also needed. The approach to recycle by-products is worth pursuing further, but requires good management skills and knowledge of by-products characteristics and processes in the soil-plant system, including the effects on species competition and thus composition of species mixtures.

\section{Acknowledgements}

This study was carried out within a project financed by the Swedish Research Council for Environment, Agricultural Sciences and Spatial Planning (Formas) and the Swedish University of Agricultural Sciences (SLU). We also like to thank Bodil Lindström for valuable criticism on the manuscript. The authors have no conflict of interest.

\section{References}

Alloway B.J. (2013) Heavy metals in soil. Trace metals and metalloids in soil and their bioavailability. 3rd ed. Dordrecht, The Netherlands: Springer.

Bakken A.K., Gautneb H., Sveistrup T., Myhr K. (2000) Crushed rocks and mine tailings applied as K fertilizers on grassland. Nutrient Cycling in Agroecosystems, 56, 53-7.

Bertilsson J., Murphy M. (2003) Effects of feeding clover silages on feed intake, milk production and digestion in dairy cows. Grass and Forage Science, 58, 309-322. 
Bucknall SA, McKelvie AD, Naylor REL. (1979) Effects of application of distillery pot ale to hill vegetation and lowland crops. Annals of Applied Biology, 93, 67-75.

Cameron D.G., Idoine N.E., Brown T.J., Patton M.A.G., McGinn C., Mankelow J.M. (2010) Directory of Mines and Quarries 2010, 9th ed. British geological survey.

Campbell N. (2009) The use of rockdust and composted materials as soil fertility amendments. PhD thesis. University of Glasgow. Available online (2013.01.28): http://theses.gla.ac.uk/617/01/2009campbelllphd.pdf.

Cope J.T., Rouse R.D. (1977) Interpretation of soil test results. In: Walsh L.M. and Beaton J.D. (eds) Soil Testing and Plant Analysis, Madison, U.S.A.: Soil science society of America. pp. 35-54.

Dahlin A.S., Edwards A.C., Lindström B.E.M., Ramezanian A., Shand C.A., Walker R.L., Watson C.A., Öborn I. (2012) Revisiting herbage sample collection and preparation procedures to minimise risks of trace element contamination. European Journal of Agronomy, 43, 33-9.

Demeyer A., Voundi Nkana J.C., Verloo M.G. (2001) Characteristics of wood ash and influence on soil properties and nutrient uptake: an overview. Bioresource Technology, 77, 287-295.

Douglas J.T., Aiken M.N., Smith C.A. (2003) Effects of five non-agricultural organic wastes on soil composition, and on the yield and nitrogen recovery of Italian ryegrass. Soil Use Management, 19, 135-8.

Edwards A.C., Coull M., Sinclair A.H., Walker R.L., Watson C.A. (2012) Elemental status (Cu, Mo, Co, B, S and Zn) of Scottish agricultural soils compared with a soil-based risk assessment. Soil Use Management, 28, 167-176.

Elgersma A., Schlepers H., Nassiri M. (2000) Interactions between perennial ryegrass (Lolium perenne L.) and white clover (Trifolium repens L.) under contrasting nitrogen availability: productivity, seasonal patterns of species composition, $\mathrm{N}_{2}$ fixation, $\mathrm{N}$ transfer and $\mathrm{N}$ recovery. Plant and Soil, 221, 281-299.

Eriksson J., Mattsson L., Söderström M. (2010) Tillståndet i svensk åkermark och gröda, data från 2001-2007 (Current status of Swedish arable soils and cereal crops. Data from the period 2001-2007). Naturvårdsverket Rapport 6349. Stockholm, Sweden: Naturvårdsverket Förlag (in Swedish with English abstract).

Etiegni L., Campbell A.G., Mahler R.L. (1991) Evaluation of wood ash disposal on agricultural land. I. Potential as soil additive and liming agent. Communication in Soil Sciences and Plant Analyses, 22, 243-256.

Eurostat (2012) Agri-environmental statistics of the European Commission. Available online (2013.01.28):

http://epp.eurostat.ec.europa.eu/statistics_explained/index.php/Agri-environmental_statistics. 
Fangmeier A., Grüters U., Högy P., Vermehren B., Jäger H-J. (1997) Effects of elevated $\mathrm{CO}_{2}$, nitrogen supply and tropospheric ozone on spring wheat. II. Nutrients (N, P, K, S, Ca, Mg, Fe, Mn, Zn). Environmental Pollution, 96, 4359.

Ferreiro A., Merino A., Díaz N., Piñeiro J. (2011) Improving the effectiveness of wood-ash fertilization in mixed mountain pastures. Grass and Forage Science, 66, 337-350.

Govasmark E., Steen A., Bakken A.K., Strøm T., Hansen S. (2005) Factors affecting the concentration of Zn, Fe and $\mathrm{Mn}$ in herbage from organic farms and in relation to dietary requirements of ruminants. Acta Agriculturae Scandinavica B-Soil and Plant, 55, 131-142.

Grigatti M., Di Girolamo G., Chincarini R., Ciavatta C., Barbanti L. (2011) Potential nitrogen mineralization, plant utilization efficiency and soil $\mathrm{CO}_{2}$ emissions following the addition of anaerobic digested slurries. Biomass and Bioenergy, 35, 4619-4629.

Gunnarsson A., Bengtsson F., Caspersen S. (2010) Use efficiency of nitrogen from biodigested plant material by ryegrass. Journal of Plant Nutrition and Soil Science, 173, 113-9.

Harris S.L., Clark D.A., Waugh C.D., Clarkson F.H. (1996) Nitrogen fertiliser effects on white clover in dairy pastures. Grassland Research Practice Series, 6, 119-124.

Hillier S. (1999) Use of an air brush to spray dry samples for X-ray powder diffraction. Clay Minerals, 34, 127-135.

Holm S. (1979) A simple sequentially rejective multiple test procedure. Scandinavian Journal of Statistics, 6, 65-70.

ISO. 1998. ISO 11277:1998. Soil quality -- Determination of particle size distribution in mineral soil material -Method by sieving and sedimentation.

Jarrell W.M., Beverly R.B. (1981) The dilution effect in plant nutrition studies. Advances in Agronomy, 34, 197-224.

Kahnt G., Pfleiderer H., Hijazi L.A. (1986) Effect of amelioration doses of rock powder and rock sand on growth of agricultural plants and on physical characteristics of sandy and clay soil. Journal of Plant Nutrition and Soil Science, 157, 169-180 (in German with English abstract).

Kopsell D.E., Kopsell D.A. (2007) Copper. In: Barker A.V., Pilbeam D.J. (eds) Handbook of plant nutrition, New York, U.S.A.: CRC Press. pp. 293-328.

Krejsl J.A., Scanlon T.M. (1996) Evaluation of beneficial use of wood-fired boiler ash on oat and bean growth. Journal of Environmental Quality, 25, 950-954. 
Lindström B.E.M. (2013). Micronutrients in temperate forage crops grown in Sweden. Diss. Uppsala : Sveriges lantbruksuniversitet, Acta Universitatis agriculturae Sueciae, 1652-6880 ; 2013:3. ISBN 978-91-576-7760-0

Lindström B.E.M, Frankow-Lindberg B.E., Dahlin A.S., Wivstad M., Watson C.A. (2013) Micronutrient concentrations in common and novel forage species and varieties grown on two contrasting soils. Grass and Forage Science, 68, 427-436.

Mengel K. (2007) Potassium. In: Barker A.V., Pilbeam D.J. (eds) Handbook of plant nutrition, New York, U.S.A.: CRC Press. pp. 91-120.

National Research Council (NRC) (2001) Nutrient requirements of dairy cattle, 7th rev, National Academy of Science, Washington, D.C., USA.

Naylor REL, Shortreed K. 1981. Grass scorch due to pot ale. Annals of Applied Biology, 99, 353-357.

Öborn I., Edwards A.C., Hillier S. (2010) Quantifying uptake rate of potassium from soil in a long-term grass rotation experiment. Plant and Soil, 335, 3-19.

Omotoso O., McCarty D.K., Hillier S., Kleeberg R. (2006) Some successful approaches to quantitative mineral analysis as revealed by the 3rd Reynolds Cup contest. Clays and Clay Minerals, 54, 748-760.

Park N.D., Rutherford P.M., Thring R.W., Helle S.S. (2012) Wood pellet fly ash and bottom ash as an effective liming agent and nutrient source for rye grass (Lolium perenne L.) and oats (Avena sativa). Chemosphere, 86, 427-432.

Parker F.W. (1929) The Origin, Nature, and Isolation of the Inorganic Base Exchange Compound of Soil. Journal of the American Society of Agronomy, 21, 1030-1039.

Paterson E. 2011. Geochemical atlas of Scottish topsoils. Edited and updated by Campbell C, Coull M, Shand S. The Macaulay Land Use Research Institute. ISBN 978-0-902701-00-7. pp 44. Available online (2014.02.05):

http://www.macaulay.ac.uk/soilquality/GeochemicalAtlas_web_aug11.pdf

Pirhofer-Walzl K., Søegaard K., Høgh-Jensen H., Eriksen J., Sanderson M. A., Rasmussen J. (2011) Forage herbs improve mineral composition of grassland herbage. Grass and Forage Science 66, 415-423.

Ramezanian A., Dahlin A.S., Campbell C.D., Hillier S., Mannerstedt-Fogelfors B., Öborn I. (2013) Addition of a volcanic rockdust to soils has no observable effects on plant yield and nutrient status or on soil microbial activity. Plant and Soil, 367, 419-436.

Reimann C., Siewers U., Tarvainen T., Bityukova L., Eriksson J., Gilucis A., Gregorauskiene V., Lukashev V., Matinian N.N., Pasieczna A. 2000. Baltic soil survey: total concentrations of major and selected trace elements in arable soils from 10 countries around the Baltic Sea. The Science of the Total Environment, 257, 155-170. 
Reith J.W.S, Burridge J.C., Berrow M.L., Caldwell K.S. (1984) Effects of fertilizers on the contents of copper and molybdenum in herbage cut for conservation. Journal of The Science of Food And Agriculture, 35, $245-256$.

Roche J.R., Turner L.R., Lee J.M., Edmeades D.C., Donaghy D.J., Macdonald K.A., Penno J.W., Berry D.P. (2009) Weather, herbage quality and milk production in pastoral systems, 3: Inter-relationships and associations between weather variables and herbage growth rate, quality and mineral concentration. Animal Production Science, 49, 211-221.

Sleugh B., Moore K.J., George J.R., Brummer E.C. (2000) Binary legume-grass mixtures improve forage yield, quality, and seasonal distribution. Agronomy Journal, 92, 24-9.

Soriano-Disla J.M., Gómez I., Navarro-Pedreño J., Lag-Brotons A. (2010) Evaluation of single chemical extractants for the prediction of heavy metal uptake by barley in soils amended with polluted sewage sludge. Plant and Soil, 327, 303-314.

Streck T., Richter J. (1997) Heavy metal displacement in a sandy soil at the field scale.1. Measurements and parameterization of sorption. Journal of Environmental Quality, 26, 49-56.

Sumner M.E. (1994) Measurement of soil-pH - problems and solutions. Communications in Soil Science and Plant Analyses, 25, 859-879.

Suttle N. (2010) Mineral nutrition of livestock, 4th ed. Wallingford, U.K.: CAB International.

Swedish Board of Agriculture. (2004) Föreskrifter om ändring i Statens jordbruksverks föreskrifter och allmänna råd (SJVFS 2004:62) om miljöhänsyn i jordbruket vad avser växtnäring (in Swedish).

Swedish Environmental Protection Agency. (1994) Naturvårdsverkets författningssamling. SNFS 1994:2 MS:72, Available online (2011.10.26):

http://www.naturvardsverket.se/Documents/foreskrifter/nfs1994/SNFS1994_02k.pdf (in Swedish).

Swedish Monitoring Program. (2013) Swedish environmental monitoring program on arable soils (database). Available on-line (2013.01.12): http://www-

jordbruksmark.slu.se/AkerWebb/MgiPub/Index.jsp?PageType=3\&PagelD=0 (in Swedish).

Swedish Standards Institute. (1993) Soil analysis. Extraction and determination of phosphorus, potassium, calcium, magnesium and sodium from soils with ammonium lactate/acetic acid solution. SS 028310. Stockholm: Swedish Standards Institute (In Swedish).

Thomas G.W. (1982) In Methods of Soil Analysis Part 2 - Chemical and Microbiological Properties. Page, A.L, Miller, R.H and Keeney, D.R. (eds) 2nd Edition SSSA, Madison. pp 159 - 165. 
Tuomisto HL, Hodge I D, Riordan P, Macdonald DW. 2012. Comparing global warming potential, energy use and land use of organic, conventional and integrated winter wheat production. Annals of Applied Biology, 161, 116126.

Whitehead D.C. (2000) Nutrient elements in grassland: Soil-plant-animal relationships. Wallingford, U.K.: Cabi.

\section{Supporting information}

Supporting information 1 All-season average clover concentration of $(A)$ macronutrients $\left(\mathrm{g} \mathrm{kg}^{-1} \mathrm{DW}\right)$ and $(B)$ micronutrients ( $\left.\mathrm{mg} \mathrm{kg}^{-1} \mathrm{DW}\right)$.

Supporting information 2 All-season average grass concentration of $(A)$ macronutrients $\left(\mathrm{g} \mathrm{kg}^{-1} \mathrm{DW}\right)$ and $(B)$ micronutrients ( $\left.\mathrm{mg} \mathrm{kg}^{-1} \mathrm{DW}\right)$.

Supporting information 3 Overall (A) macronutrient $\left(\mathrm{g} \mathrm{kg}^{-1} \mathrm{DW}\right)$ and $(\mathrm{B})$ micronutrient $\left(\mathrm{mg} \mathrm{kg}^{-1} \mathrm{DW}\right)$ concentrations of grass-clover mixture.

Supporting information 4 Accumulated off-take of $(A)$ macronutrients $\left(\mathrm{g} \mathrm{m}^{-2}\right)$ and $(B)$ micronutrients $\left(\mathrm{mg} \mathrm{m}^{-2}\right)$ by the grass-clover mixture.

Supporting information 5 Correlations between plant nutrient concentrations and soil pH, plant biomass (g DW) production and soil EDTA extractable concentrations of the same nutrient. 
Table 1 Original characteristics of the two soils (Hollsby and Rådde) used in the pot experiment; total and extractable $\left(A L^{a}\right.$ or EDTA) concentrations of nutrients

\begin{tabular}{|c|c|c|c|c|}
\hline Soil & \multicolumn{2}{|c|}{ Hollsby } & \multicolumn{2}{|c|}{ Rådde } \\
\hline Characteristic & $\begin{array}{l}\text { Total } \\
\mathrm{g} \mathrm{kg}^{-1}\end{array}$ & $\begin{array}{c}\mathrm{AL} \\
\mathrm{mg} \mathrm{kg}^{-1}\end{array}$ & $\begin{array}{l}\text { Total } \\
\mathrm{g} \mathrm{kg}^{-1}\end{array}$ & $\begin{array}{c}\mathrm{AL} \\
\mathrm{mg} \mathrm{kg}^{-1}\end{array}$ \\
\hline $\mathrm{N}$ & 1.9 & na & 2.8 & na \\
\hline$P$ & 0.78 & 13 & 1.19 & 51 \\
\hline K & 25 & 23 & 20.6 & 53 \\
\hline $\mathrm{Ca}$ & 9.98 & 490 & 11.4 & 1020 \\
\hline $\mathrm{Mg}$ & 3.01 & 12 & 3.51 & 55 \\
\hline$S$ & 0.33 & na & 0.48 & na \\
\hline & $\begin{array}{l}\text { Total } \\
\text { mg kg }\end{array}$ & $\begin{array}{l}\text { EDTA } \\
\mathrm{mg} \mathrm{kg}^{-1}\end{array}$ & $\begin{array}{l}\text { Total } \\
\text { mg kg }\end{array}$ & $\begin{array}{c}\text { EDTA } \\
\mathrm{mg} \mathrm{kg}^{-1}\end{array}$ \\
\hline Co & 2.6 & 0.07 & 3.8 & 0.02 \\
\hline $\mathrm{Cu}$ & 6.9 & 2.3 & 6.5 & 0.7 \\
\hline $\mathrm{Mn}$ & 531 & 35 & 431 & 8 \\
\hline Mo & 0.40 & $b d^{b}$ & 0.85 & bd \\
\hline $\mathrm{Zn}$ & 46 & 4.6 & 30 & 2.3 \\
\hline
\end{tabular}

\footnotetext{
a ammonium lactate/acetic acid solution

${ }^{\mathrm{b}}$ below detection limit
} 
Table 2 Original characteristics of the two soils (Hollsby and Rådde) used in the pot experiment. Clay, silt and sand fractions are given as \% of the mineral fraction

\begin{tabular}{lcc}
\hline \multirow{2}{*}{ Characteristic } & \multicolumn{2}{c}{ Soil } \\
& Hollsby & Rådde \\
\hline Clay (\%) & 4 & 8 \\
Silt (\%) & 69 & 31 \\
Sand (\%) & 27 & 61 \\
pH ${ }_{\text {Cacl2 }}$ & 4.8 & 5.2 \\
CEC (cmol+c kg ${ }^{-1}$ ) & 9 & 13 \\
BS (\%) & 40 & 52 \\
SOC (\%) & 2.2 & 3.5 \\
Quartz (\%) & 53 & 52 \\
K-feldspar (\%) & 17 & 15 \\
Plagioclase (\%) & 19 & 19 \\
Amphibole (\%) & 2 & 4 \\
Dioctahedral phyllosilicates(\%) & 4 & 4 \\
Trioctahedra phyllosilicates(\%) & 3 & 4 \\
Iron oxides (\%) & 1 & 1 \\
\hline
\end{tabular}


Table 3 Characteristics of the waste products biogas digestate (BD), pot ale (PA), rock dust (RD) and wood ash (WA), waste product and nutrient application rates used in the experiment. The nutrient or non-nutrient element limiting the application rate of waste products is given in bold. Application rates of $\mathrm{N}$, $\mathrm{P}$ and $\mathrm{K}$ presented separately up to and after second harvest. ${ }^{a}$ denotes the limiting element according to SEPA if $\mathrm{N}$ application via waste products had not been targeted to $15 \mathrm{~g} \mathrm{~m}^{-2}$. ${ }^{\mathrm{b}}$ denotes the nutrient was added in solution. ${ }^{\mathrm{C}}$ denotes the nutrient was added as dry salt

\begin{tabular}{|c|c|c|c|c|c|c|c|c|c|c|c|c|c|}
\hline & \multicolumn{5}{|c|}{ Amendment characteristics } & \multicolumn{8}{|c|}{ Application rates } \\
\hline & unit & PA & $\mathrm{BD}$ & RD & WA & unit & $\mathrm{FF}$ & PA & $\mathrm{BD}$ & RD-N & $\mathrm{RD}+\mathrm{N}$ & WA-N & $W A+N$ \\
\hline Amount product & & na & na & na & na & $\mathrm{kg} \mathrm{m}^{-2}$ & na & 8.5 & 1.5 & 5.0 & 5.0 & 0.14 & 0.14 \\
\hline Liming effect & $\% \mathrm{CaO}$ & -4 & 6.2 & 1.9 & 51.3 & & na & na & na & na & na & na & na \\
\hline C & $\%$ & 47 & 42 & 0.005 & 1.1 & $\mathrm{~g} \mathrm{~m}^{-2}$ & - & 126 & 177 & - & - & 1.5 & 1.5 \\
\hline N & $\mathrm{g} \mathrm{kg}^{-1}$ & 58 & 24 & 1.0 & 0.1 & $\mathrm{~g} \mathrm{~m}^{-2}$ & $13^{c}+2^{b}$ & $15+2^{b}$ & $15+2^{b}$ & - & $13+2^{b}$ & 0.008 & $13+2^{b}$ \\
\hline$P$ & $\mathrm{~g} \mathrm{~kg}^{-1}$ & 15 & 8.2 & 1.2 & 21 & $\mathrm{~g} \mathrm{~m}^{-2}$ & $18.8+7.5^{c}$ & $3.9+7.5^{c}$ & $3.4+7.5^{c}$ & $6.0+7.5^{c}$ & $6.0+7.5^{c}$ & $3.1+7.5^{c}$ & $3.1+7.5^{c}$ \\
\hline K & $\mathrm{g} \mathrm{kg}^{-1}$ & 32 & 12 & 2.6 & 69 & $\mathrm{~g} \mathrm{~m}^{-2}$ & $26.5^{c}+4.2^{b}$ & $8.6+4.2^{b}$ & $4.9+4.2^{b}$ & $12.8+4.2^{b}$ & $12.8+4.2^{b}$ & $10.0+4.2^{b}$ & $10.0+4.2^{b}$ \\
\hline $\mathrm{Ca}$ & $\mathrm{g} \mathrm{kg}^{-1}$ & 1.7 & 49 & 13 & 324 & $\mathrm{~g} \mathrm{~m}^{-2}$ & $143^{c}$ & 0.44 & 20.3 & 65.8 & 65.8 & 46.9 & 46.9 \\
\hline $\mathrm{Mg}$ & $\mathrm{g} \mathrm{kg}^{-1}$ & 6.0 & 6.2 & 17 & 40 & $\mathrm{~g} \mathrm{~m}^{-2}$ & $19.6^{b}$ & 1.58 & 2.58 & 84.1 & 84.1 & 5.79 & 5.79 \\
\hline S & $\mathrm{g} \mathrm{kg}^{-1}$ & 4.2 & 3.1 & 0.09 & 0.82 & $\mathrm{~g} \mathrm{~m}^{-2}$ & $3.91^{b}$ & 1.10 & 1.28 & 0.46 & 0.46 & 0.12 & 0.12 \\
\hline Co & $\mathrm{mg} \mathrm{kg}^{-1}$ & 0.07 & 0.89 & 12 & 21 & $\mathrm{mg} \mathrm{m}^{-2}$ & - & 0.02 & 0.4 & 59 & 59 & 3.0 & 3.0 \\
\hline $\mathrm{Cu}$ & $\mathrm{mg} \mathrm{kg}^{-1}$ & $177^{\mathrm{a}}$ & 29 & 7.3 & 118 & $\mathrm{mg} \mathrm{m}^{-2}$ & $4.3^{b}$ & 47 & 12 & 36 & 36 & 17 & 17 \\
\hline $\mathrm{Mn}$ & $\mathrm{mg} \mathrm{kg}^{-1}$ & 16 & 215 & 375 & 7810 & $\mathrm{mg} \mathrm{m}^{-2}$ & $98^{b}$ & 4.3 & 90 & 1850 & 1850 & 1130 & 1130 \\
\hline Mo & $\mathrm{mg} \mathrm{kg}^{-1}$ & 0.45 & 1.9 & 0.20 & $<6$ & $\mathrm{mg} \mathrm{m}^{-2}$ & $0.04^{b}$ & 0.1 & 0.8 & 1.0 & 1.0 & 0.4 & 0.4 \\
\hline $\mathrm{Zn}$ & $\mathrm{mg} \mathrm{kg}^{-1}$ & 21 & 76 & 46 & 182 & $\mathrm{mg} \mathrm{m}^{-2}$ & $0.2^{b}$ & 5.6 & 32 & 228 & 228 & 26 & 26 \\
\hline
\end{tabular}

5 
Table 4 Soil pH, electrical conductivity (EC) and EDTA extractable nutrient concentrations (macronutrients in $\mathrm{g} \mathrm{kg}^{-1} \mathrm{DW}$ soil; micronutrients in mg kg ${ }^{-1}$ DW) 14 months after fertilisation and by-product amendment; fully fertilized (FF), biogas digestate (BD), pot ale (PA), rock dust (RD) and wood ash (WA). Data given as LSMeans \pm SEM of four replicates, $\mathrm{df}=7$

\begin{tabular}{|c|c|c|c|c|c|c|c|c|}
\hline & Control & $\mathrm{FF}$ & PA & $\mathrm{BD}$ & $\mathrm{RD}-\mathrm{N}$ & $\mathrm{RD}+\mathrm{N}$ & WA - N & $W A+N$ \\
\hline \multicolumn{9}{|c|}{ Hollsby } \\
\hline $\mathrm{pH}$ & $5.0 \pm 0.0$ & $5.1 \pm 0.1$ & $4.9 \pm 0.1$ & $5.0 \pm 0.0$ & $5.0 \pm 0.0$ & $5.1 \pm 0.1$ & $5.3 \pm 0.0$ & $5.4 \pm 0.0$ \\
\hline $\mathrm{EC}$ & $93 \pm 6$ & $211 \pm 16$ & $97 \pm 6$ & $104 \pm 4$ & $104 \pm 4$ & $103 \pm 1$ & $118 \pm 3$ & $122 \pm 3$ \\
\hline$P$ & $0.026 \pm 0.001$ & $0.027 \pm 0.002$ & $0.029 \pm 0.001$ & $0.029 \pm 0.001$ & $0.027 \pm 0.002$ & $0.025 \pm 0.002$ & $0.027 \pm 0.001$ & $0.028 \pm 0.001$ \\
\hline K & $0.020 \pm 0.001$ & $0.030 \pm 0.002$ & $0.033 \pm 0.003$ & $0.027 \pm 0.001$ & $0.021 \pm 0.001$ & $0.026 \pm 0.001$ & $0.034 \pm 0.002$ & $0.042 \pm 0.001$ \\
\hline $\mathrm{Ca}$ & $0.99 \pm 0.03$ & $0.77 \pm 0.02$ & $1.03 \pm 0.02$ & $1.08 \pm 0.06$ & $1.00 \pm 0.01$ & $1.04 \pm 0.02$ & $1.21 \pm 0.02$ & $1.26 \pm 0.03$ \\
\hline $\mathrm{Mg}$ & $0.016 \pm 0.001$ & $0.040 \pm 0.001$ & $0.021 \pm 0.001$ & $0.016 \pm 0.001$ & $0.022 \pm 0.003$ & $0.026 \pm 0.001$ & $0.029 \pm 0.001$ & $0.033 \pm 0.001$ \\
\hline Co & $0.15 \pm 0.01$ & $0.21 \pm 0.02$ & $0.13 \pm 0.01$ & $0.13 \pm 0.01$ & $0.13 \pm 0.01$ & $0.13 \pm 0.01$ & $0.11 \pm 0.01$ & $0.11 \pm 0.01$ \\
\hline $\mathrm{Cu}$ & $1.4 \pm 0.1$ & $1.1 \pm 0.0$ & $2.0 \pm 0.1$ & $1.5 \pm 0.0$ & $1.4 \pm 0.1$ & $1.4 \pm 0.1$ & $1.6 \pm 0.1$ & $1.6 \pm 0.1$ \\
\hline $\mathrm{Mn}$ & $26 \pm 1$ & $64 \pm 4$ & $22 \pm 2$ & $23 \pm 1$ & $21 \pm 2$ & $22 \pm 3$ & $22 \pm 2$ & $22 \pm 2$ \\
\hline Mo & $0.025 \pm 0.007$ & $0.056 \pm 0.027$ & $0.024 \pm 0.011$ & $0.018 \pm 0.000$ & $0.021 \pm 0.003$ & $0.011 \pm 0.004$ & $0.019 \pm 0.002$ & $0.019 \pm 0.002$ \\
\hline $\mathrm{Zn}$ & $3.6 \pm 0.2$ & $5.4 \pm 0.2$ & $3.7 \pm 0.1$ & $3.8 \pm 0.3$ & $3.4 \pm 0.1$ & $3.2 \pm 0.1$ & $4.0 \pm 0.5$ & $3.6 \pm 0.2$ \\
\hline \multicolumn{9}{|c|}{ Rådde } \\
\hline $\mathrm{pH}$ & $4.6 \pm 0.1)$ & $5.0 \pm 0.1$ & $4.7 \pm 0.1$ & $4.7 \pm 0.0$ & $4.7 \pm 0.1$ & $4.8 \pm 0.1$ & $5.2 \pm 0.0$ & $5.2 \pm 0.0$ \\
\hline EC & $85 \pm 8$ & $223 \pm 8$ & $88 \pm 6$ & $100 \pm 9$ & $80 \pm 2$ & $84 \pm 4$ & $112 \pm 2$ & $104 \pm 3$ \\
\hline $\mathrm{P}$ & $0.010 \pm 0.000$ & $0.030 \pm 0.004$ & $0.015 \pm 0.001$ & $0.014 \pm 0.002$ & $0.011 \pm 0.001$ & $0.010 \pm 0.001$ & $0.014 \pm 0.001$ & $0.013 \pm 0.001$ \\
\hline K & $0.015 \pm 0.001$ & $0.029 \pm 0.003$ & $0.023 \pm 0.002$ & $0.020 \pm 0.001$ & $0.013 \pm 0.001$ & $0.014 \pm 0.001$ & $0.028 \pm 0.003$ & $0.034 \pm 0.004$ \\
\hline $\mathrm{Ca}$ & $0.55 \pm 0.01$ & $0.89 \pm 0.07$ & $0.56 \pm 0.02$ & $0.65 \pm 0.04$ & $0.65 \pm 0.05$ & $0.56 \pm 0.01$ & $0.81 \pm 0.01$ & $0.82 \pm 0.01$ \\
\hline $\mathrm{Mg}$ & $0.005 \pm 0.000$ & $0.040 \pm 0.002$ & $0.009 \pm 0.001$ & $0.007 \pm 0.000$ & $0.014 \pm 0.000$ & $0.013 \pm 0.000$ & $0.018 \pm 0.001$ & $0.019 \pm 0.001$ \\
\hline Co & $0.23 \pm 0.02$ & $0.21 \pm 0.01$ & $0.26 \pm 0.01$ & $0.22 \pm 0.02$ & $0.22 \pm 0.02$ & $0.23 \pm 0.01$ & $0.18 \pm 0.01$ & $0.19 \pm 0.01$ \\
\hline
\end{tabular}




\begin{tabular}{llllllll}
$\mathrm{Cu}$ & $1.1 \pm 0.0$ & $1.1 \pm 0.0$ & $1.5 \pm 0.0$ & $1.2 \pm 0.0$ & $1.1 \pm 0.0$ & $1.1 \pm 0.0$ & $1.2 \pm 0.0$ \\
$\mathrm{Mn}$ & $73 \pm 4$ & $62 \pm 3$ & $86 \pm 3$ & $72 \pm 4$ & $67 \pm 4$ & $69 \pm 4$ & $60 \pm 3$ \\
$\mathrm{Mo}$ & $0.023 \pm 0.004$ & $0.050 \pm 0.022$ & $0.019 \pm 0.002$ & $0.023 \pm 0.005$ & $0.019 \pm 0.001$ & $0.021 \pm 0.002$ & $0.020 \pm 0.003$ \\
$\mathrm{Zn}$ & $5.7 \pm 0.3$ & $4.9 \pm 0.1$ & $5.7 \pm 0.3$ & $5.4 \pm 0.4$ & $5.9 \pm 1.0$ & $5.2 \pm 0.2$ & $4.4 \pm 0.2$ \\
\hline
\end{tabular}




\section{Figure captions}

Figure 1 Biomass production ( $\mathrm{g} \mathrm{DW} \mathrm{m}^{-2}$ ) and botanical composition (proportion of clover) in the grass-clover mixture grown on (A) Hollsby and (B) Rådde soil. Data are given as LSMeans with error bars indicating SEM of four replicates, $\mathrm{df}=7$.

Figure 2 Relative all-season average nutrient concentrations of clover grown on (A) Hollsby and (B) Rådde soil, expressed as a percentage of the unamended control. Data given as LSMeans with error bars indicating SEM of four replicates, $\mathrm{df}=6$.

Figure 3 Relative all-season average nutrient concentrations of grass grown on (A) Hollsby and (B) Rådde soil, expressed as a percentage of the unamended control. Data given as LSMeans with error bars indicating SEM of four replicates, $\mathrm{df}=6$.

Figure 4 Relative overall nutrient concentrations of grass-clover mixture grown on (A) Hollsby and (B) Rådde soil, expressed as a percentage of the unamended control. Data given as LSMeans with error bars indicating SEM of four replicates, $\mathrm{df}=6$. 
Figure 1A

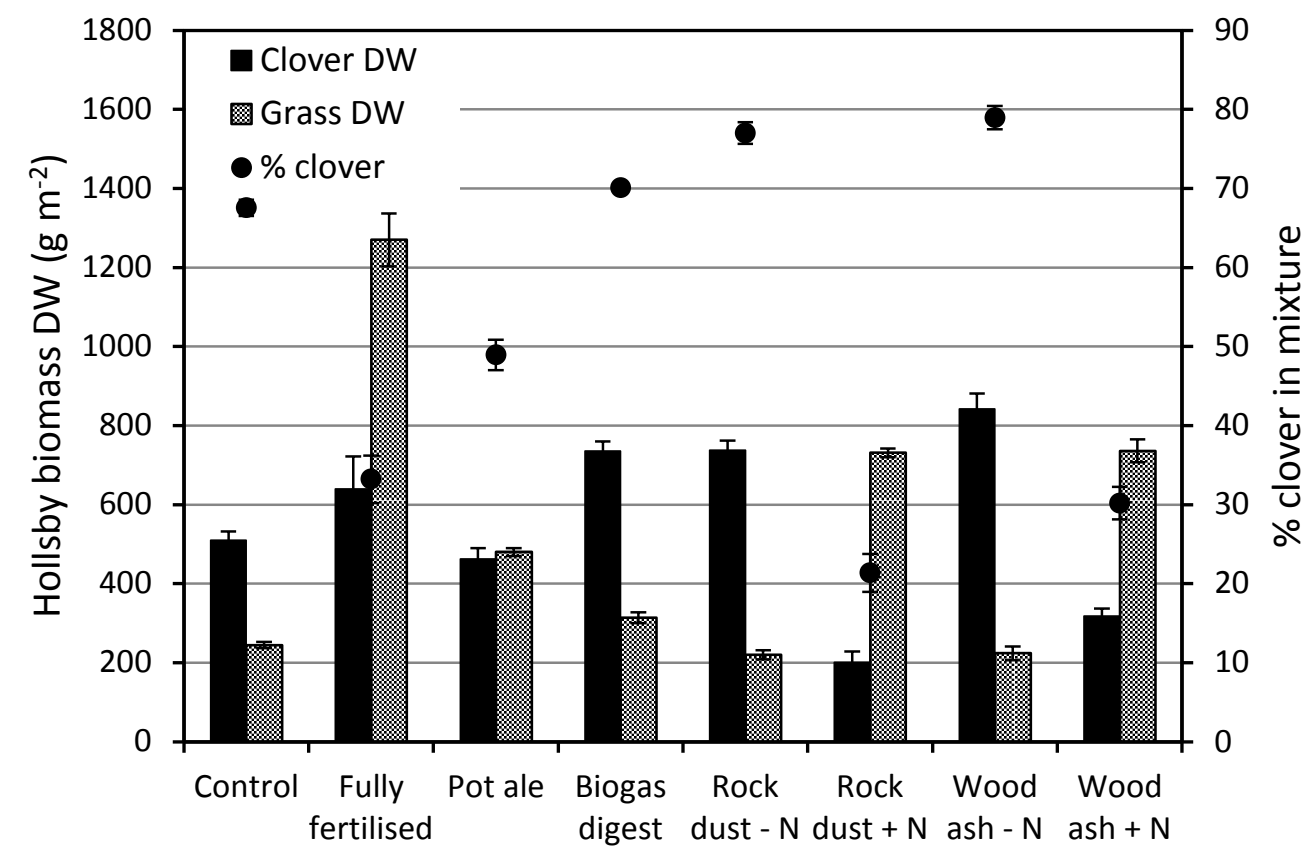




\section{Figure 1B}

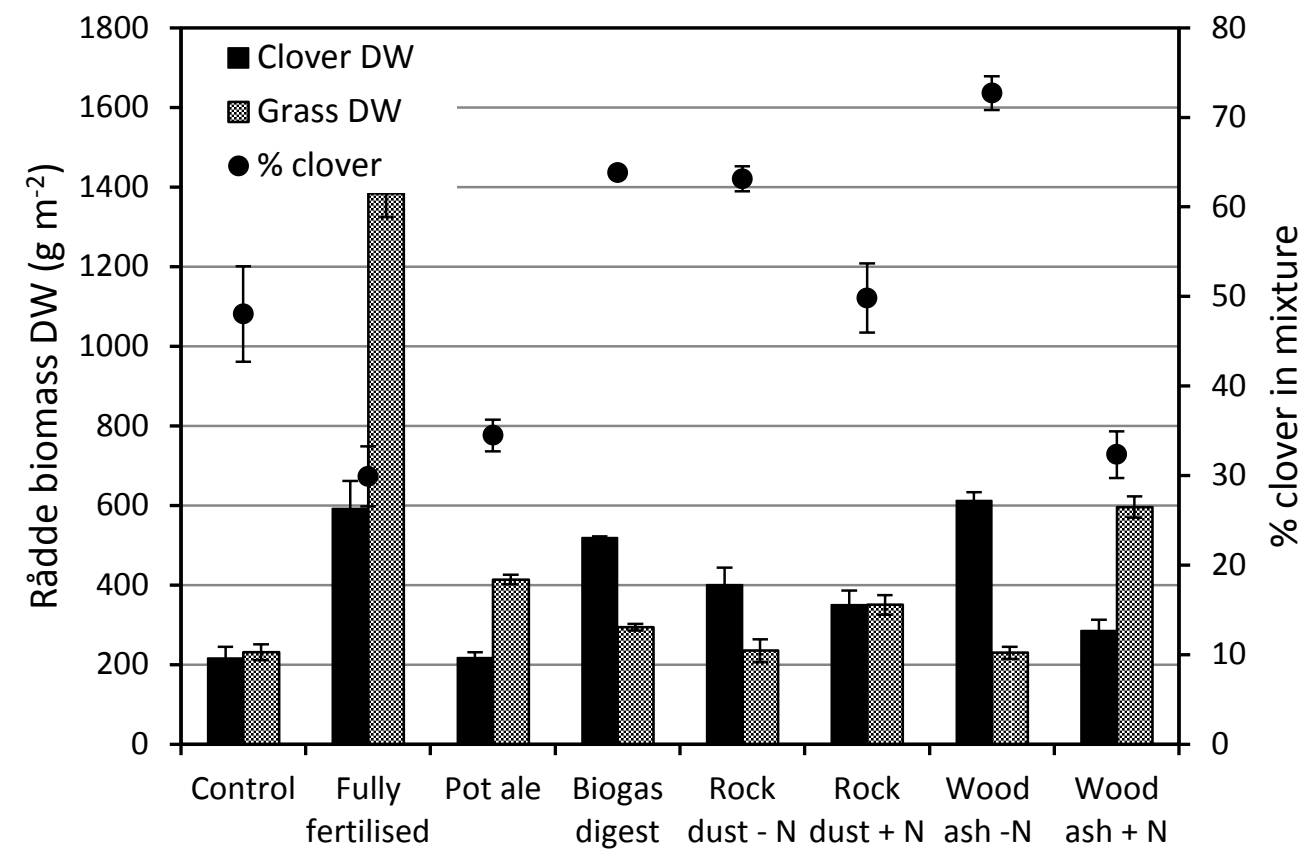


Figure 2A

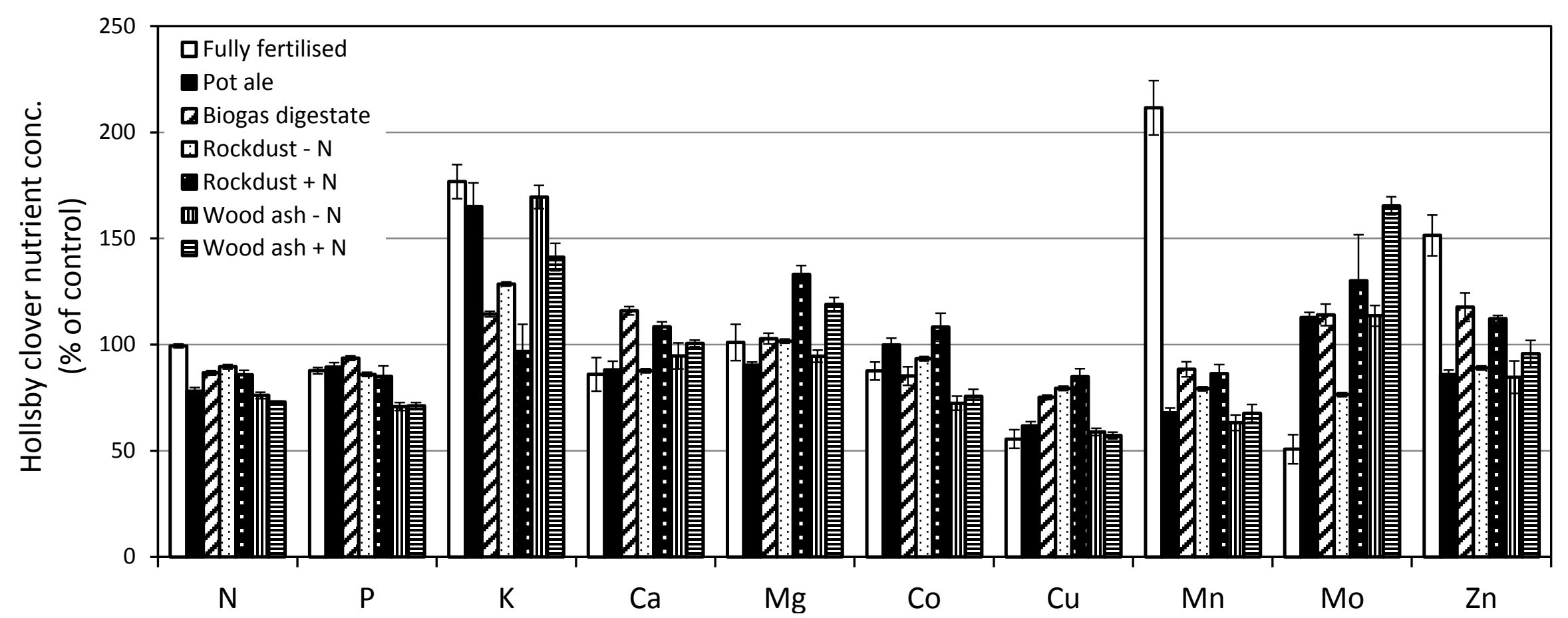


Figure 2B

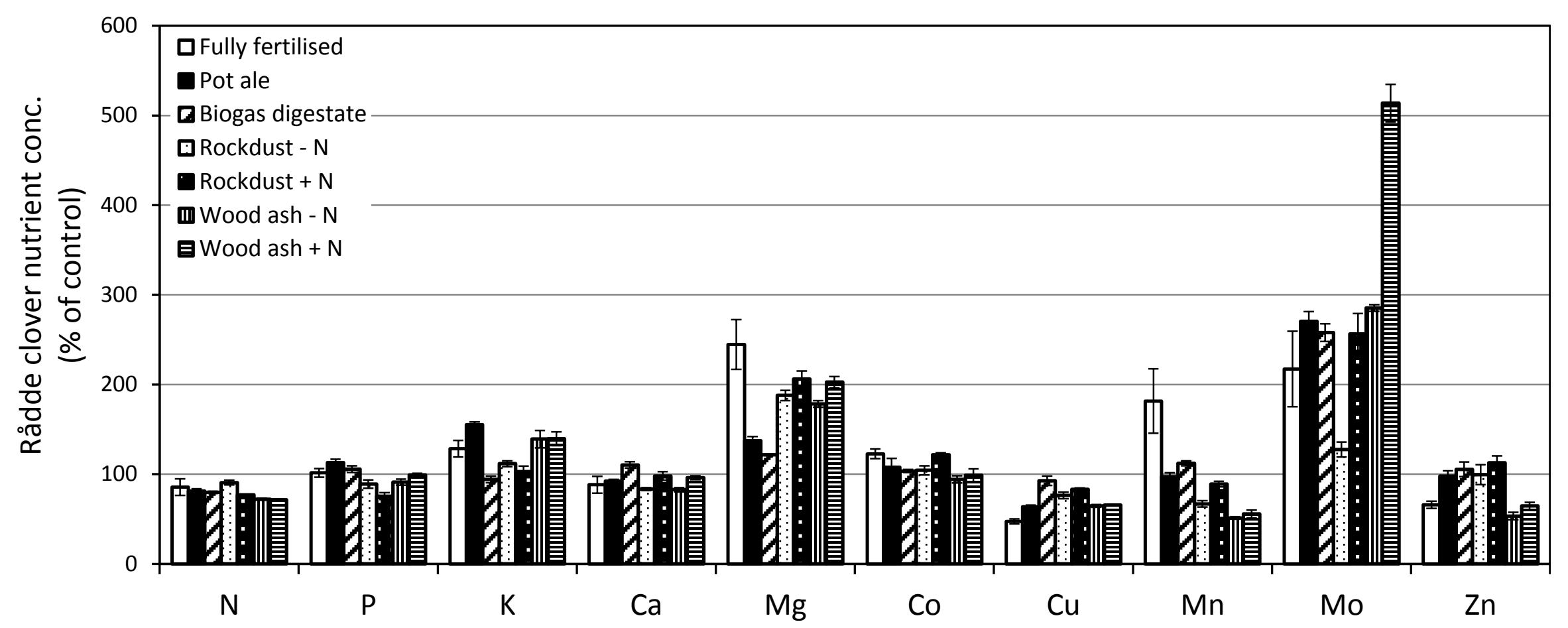


Figure 3A

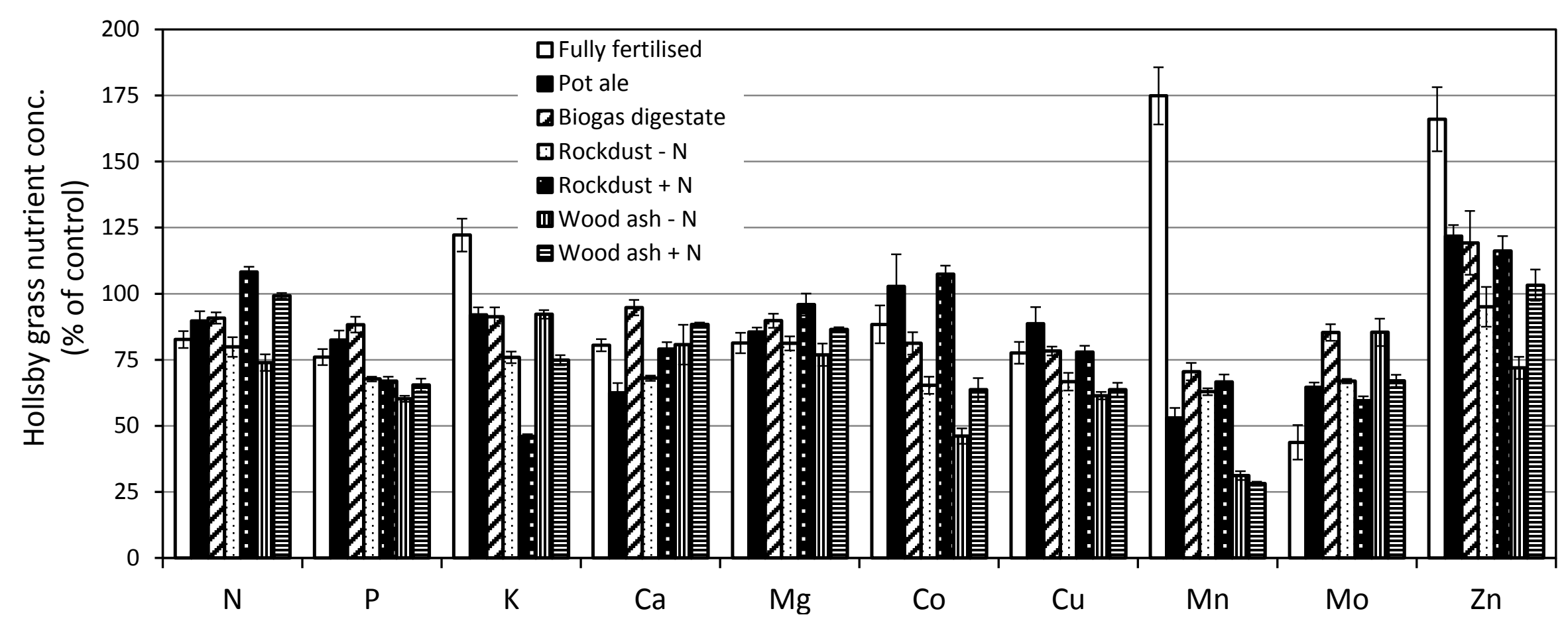


Figure 3B

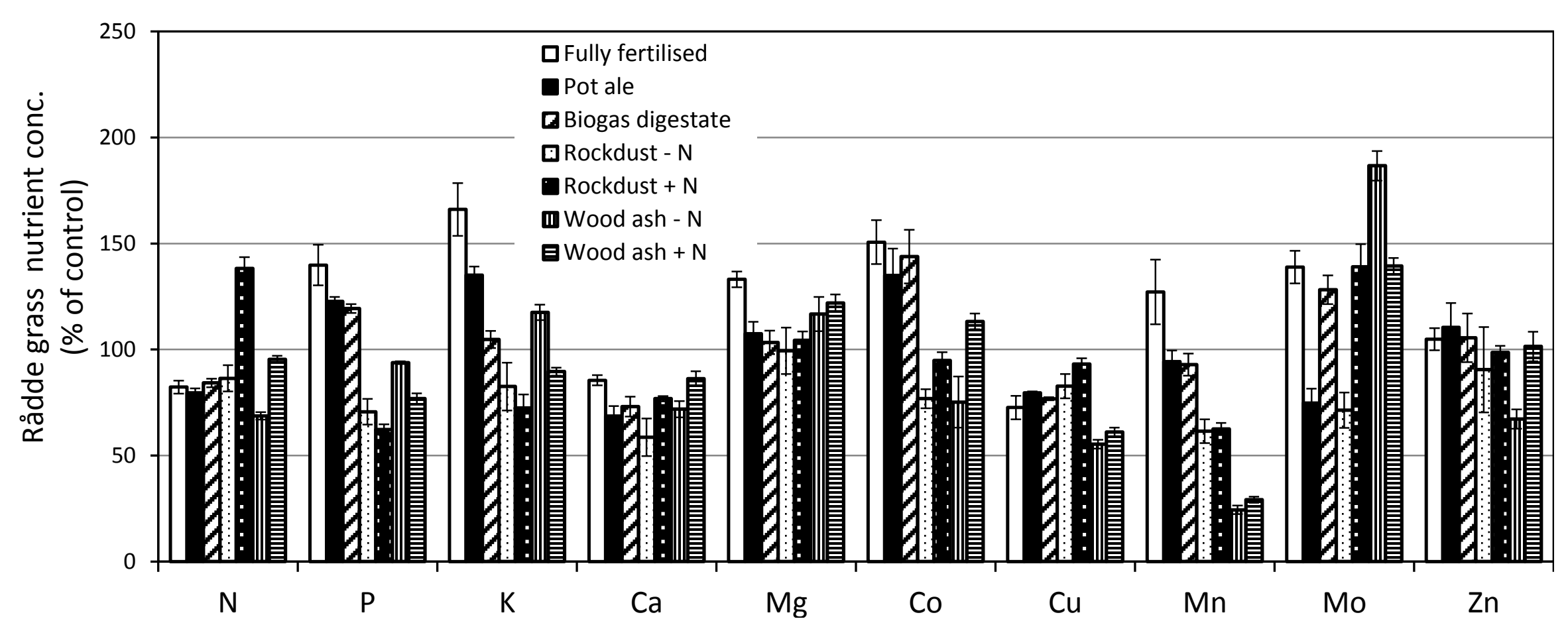


Figure 4A

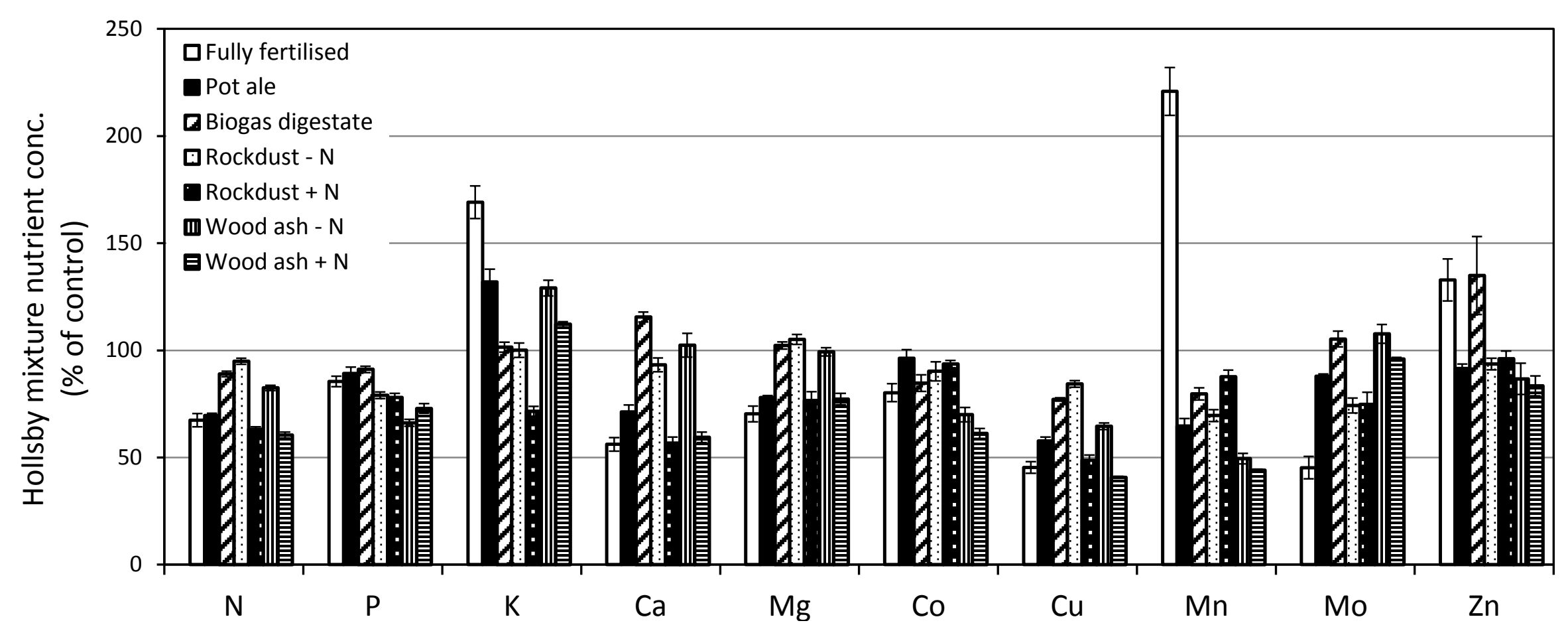


Figure 4B

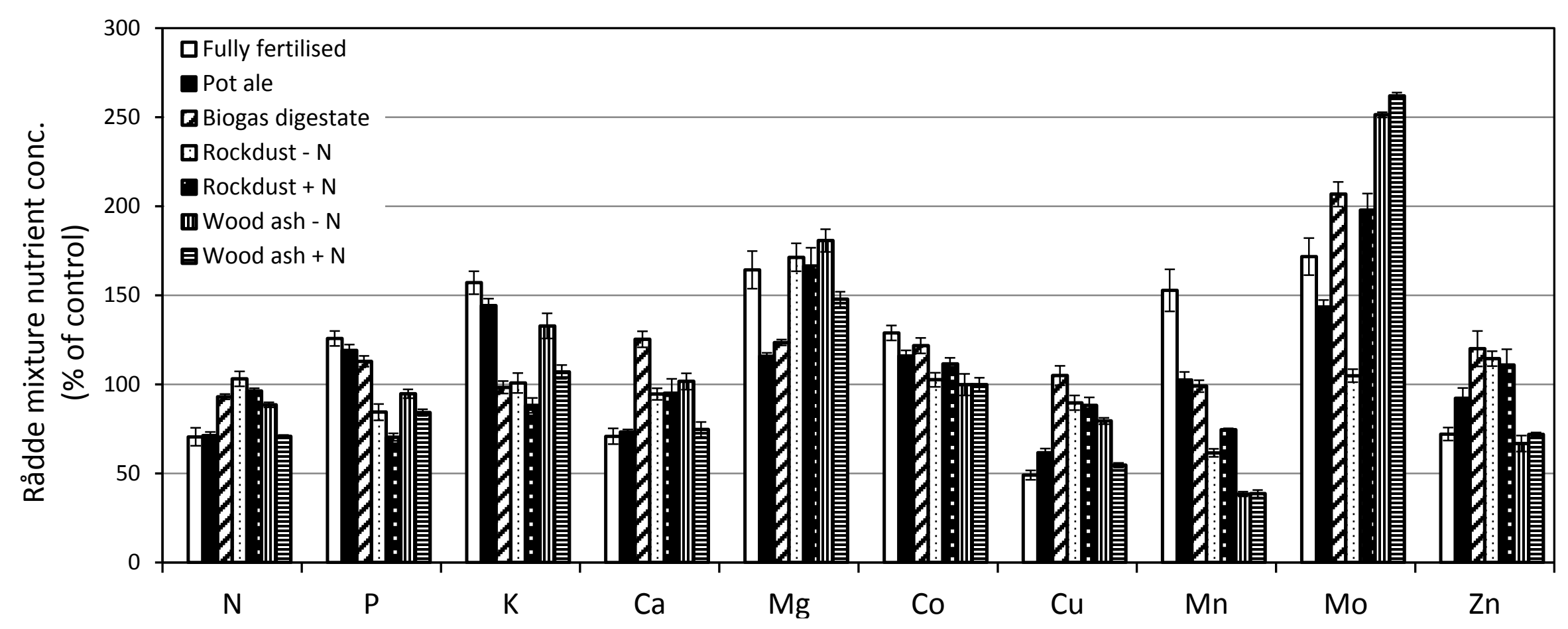

